\title{
Atypical posthypoxic MRI changes in hypermetabolic regions in anti-NMDA-receptor encephalitis
}

Figure Imaging

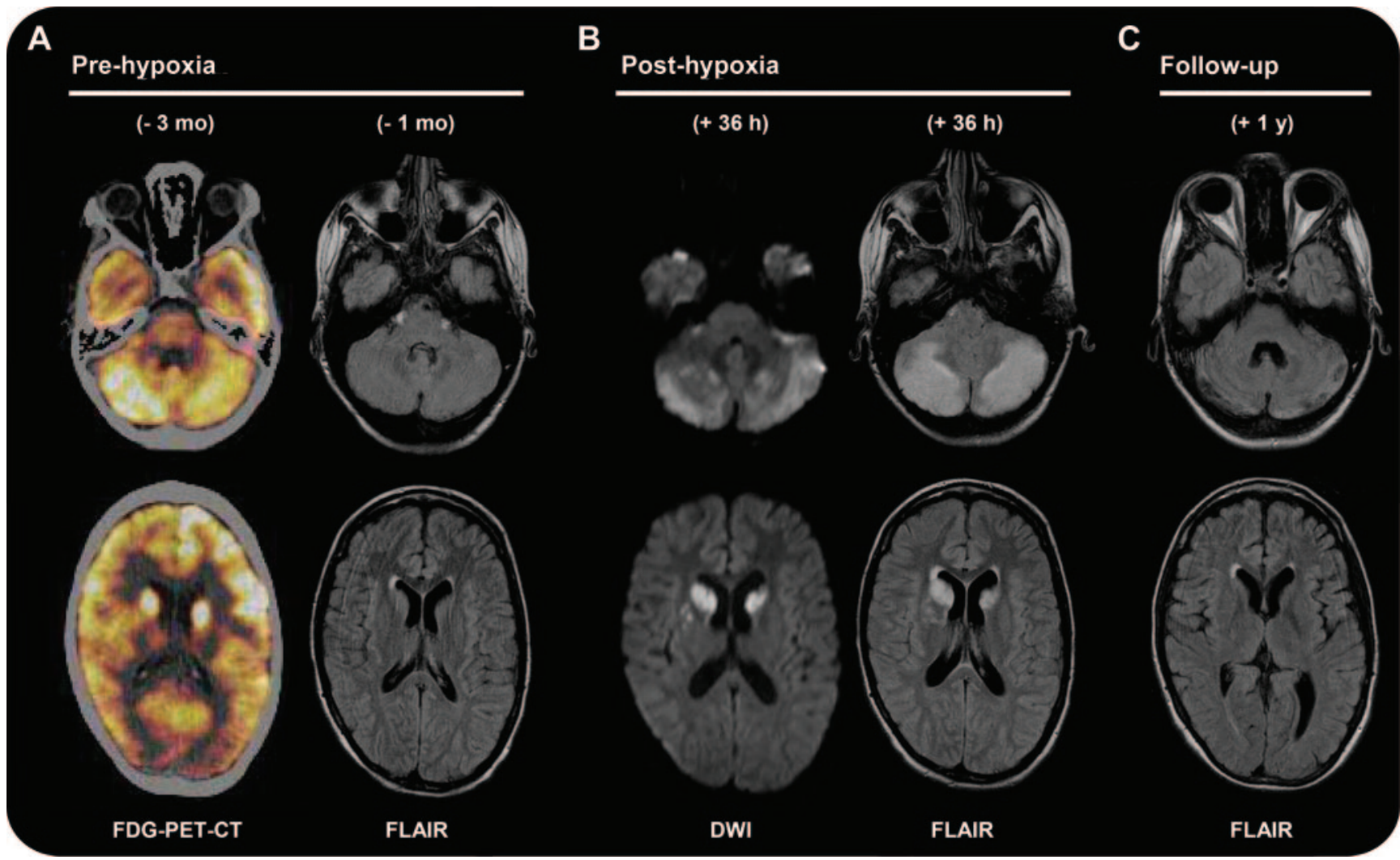

(A) Acute phase of disease (3 months before hypoxic event) showing symmetric bilateral hypermetabolism in caudate nuclei, cerebellar cortex, and left frontal cortex in $\mathrm{F}^{18}$-FDG-PET-CT imaging and normal fluid-attenuated inversion recovery (FLAIR) MRI at 2 months follow-up. (B) After the indicated episode of hypoxia, a repeat MRI showed diffusion-weighted imaging (DWI) and FLAIR abnormalities in exactly the same regions of prehypoxic FDG hypermetabolism except for the left frontal cortex. Note the unusual location of these posthypoxic MRI changes compared to the typical manifestation of regions expected to be affected according models of pure hypoxic brain injury (i.e., neocortex, hippocampus, putamen). (C) One-year follow-up shows cerebellar lesions and caudate nuclei atrophy.

A 20-year-old woman with severe anti-NMDA-receptor encephalitis ${ }^{1}$ had repeated normal brain MRI findings, however, $\mathrm{F}^{18}$-FDG-PET-CT demonstrated hypermetabolism in caudate nuclei ${ }^{2}$ and cerebellum ${ }^{3}$ (figure, A). Under multimodal immunotherapy, she improved substantially. A sudden hypoxic period during a seizure $\left(\mathrm{O}_{2}\right.$ saturation $34 \% ;<5$ minutes) produced an unusual distribution of MRI changes (figure, $\mathrm{B}$ and $\mathrm{C}$ ).

The striking correlation between prehypoxic FDG-PET hypermetabolism and posthypoxic MRI changes plus the atypical distribution of the findings suggest increased susceptibility of these areas to hypoxia in anti-NMDA-receptor encephalitis. This is of significance since hypoxic episodes such as seizures, cardiac arrest, or respiratory failure are frequent in these patients. ${ }^{1}$

Albrecht Günther, MD, Stefan Brodoehl, MD, Otto W. Witte, MD, Martin Freesmeyer, MD, Jena, Germany; Josep O. Dalmau, MD, Barcelona, Spain, and Philadelphia, PA; Christoph Redecker, MD, Jena, Germany

Author contributions: A. Günther is corresponding author responsible for the study concept, interpretation of the data, as well as drafting and revising the manuscript. S. Brodoehl qualifies as author based on his contribution towards drafting the manuscript. O.W. Witte qualifies as an author due to his contribution for drafting the manuscript and interpretation of the data. M. Freesmeyer 
qualifies as an author because of his contribution in analyzing and interpreting the data. J. Dalmau qualifies as an author based on his contribution in interpreting the data as well as drafting and revising the manuscript. C. Redecker qualifies as an author based on his contribution for study concept, interpretation of the data, and drafting the manuscript.

Acknowledgment: The authors thank Nasim Kroegel for critically reviewing the manuscript.

The authors report no disclosures relevant to the manuscript. Go to Neurology.org for full disclosures.

Correspondence \& reprint requests to Dr. Günther: albrecht.guenther@med.uni-jena.de

1. Dalmau J, Lancaster E, Martinez-Hernandez E, et al. Experience and Investigations on Anti-NMDA receptor encephalitis. Lancet Neurol 2011;10:63-74.

2. Maeder-Ingvar M, Prior JO, Irani SR, et al. FDG-PET hyperactivity in basal ganglia correlating with clinical course in anti-NDMA-R antibodies encephalitis. J Neurol Neurosurg Psychiatry 2011;82:235-256.

3. Maqbool M, Oleske DA, Huq AH, Salman BA, Khodabakhsh K, Chugani HT. Novel FDG-PET findings in anti-NMDA receptor encephalitis: a case based report. J Child Neurol 2011;26:1325-1328.

\section{NeuroImages Are Free at www.neurology.org!}

All Neurology ${ }^{\circledR}$ NeuroImages can now be freely accessed on the Neurology Web site. See them at www.neurology.org, where you can also sign up for journal email alerts and check out other online features, including the Resident \& Fellow section, Neurology: Clinical Practice, and the weekly Neurology Podcasts. 


\section{Neurology}

\section{Atypical posthypoxic MRI changes in hypermetabolic regions in anti-NMDA-receptor encephalitis}

Albrecht Günther, Stefan Brodoehl, Otto W. Witte, et al. Neurology 2012;79;720-721

DOI 10.1212/WNL.0b013e3182648bdc

\section{This information is current as of August 13, 2012}

\section{Updated Information \& Services}

References

Citations

Subspecialty Collections

Permissions \& Licensing

Reprints including high resolution figures, can be found at: http://n.neurology.org/content/79/7/720.full

This article cites 3 articles, 1 of which you can access for free at: http://n.neurology.org/content/79/7/720.full\#ref-list-1

This article has been cited by 2 HighWire-hosted articles: http://n.neurology.org/content/79/7/720.full\#\#otherarticles

This article, along with others on similar topics, appears in the following collection(s):

\section{Autoimmune diseases}

http://n.neurology.org/cgi/collection/autoimmune_diseases

Critical care

http://n.neurology.org/cgi/collection/critical_care

DWI

http://n.neurology.org/cgi/collection/dwi

MRI

http://n.neurology.org/cgi/collection/mri

PET

http://n.neurology.org/cgi/collection/pet

Information about reproducing this article in parts (figures,tables) or in its entirety can be found online at:

http://www.neurology.org/about/about_the_journal\#permissions

Information about ordering reprints can be found online:

http://n.neurology.org/subscribers/advertise

Neurology ${ }^{\circledR}$ is the official journal of the American Academy of Neurology. Published continuously since 1951, it is now a weekly with 48 issues per year. Copyright Copyright (? 2012 by AAN Enterprises, Inc.. All rights reserved. Print ISSN: 0028-3878. Online ISSN: 1526-632X.

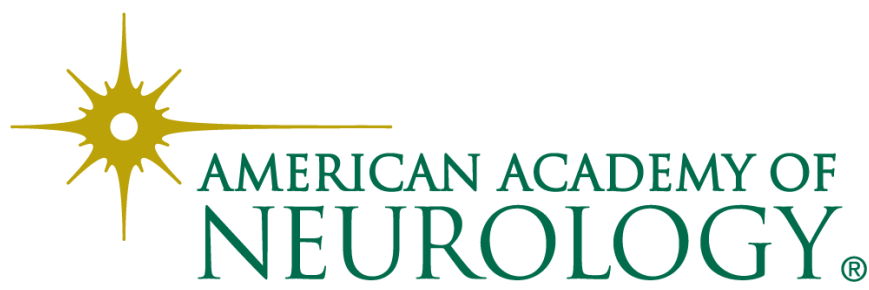

